\title{
Income and disbursement of Urban Local Bodies: A Study of Kurnool Municipal Corporation
}

\author{
Samadri Muniswami
}

Research Scholar Department of Economics Rayalaseema University Kurnool. Andhra Pradesh

\begin{abstract}
The ancient India which was famous for its 'village republics', was also a land of big and well administered cities and towns. The excavations of Harappa and Mohenjodaro have brought out the remains of well-run cities. Kautilya, in His renowned treatise on 'Arthshastra', has given a graphic description of the city of Patliputra, the capital of the great Mauryas, and its administration. Megasthenese, the Greek ambassador to the court of Chandra Gupta Maurya, has also left a description of the city of Patliputra. The cities continued to flourish under the Muslim rule and reached the peak of their glory under the Mughals. The Britishers also developed cities like Bombay, Calcutta and Madras. This trend towards growing urbanization has continued unabated since 1947. The later half of the twentieth century has witnessed a marked shift of population from rural to urban areas. The accelerated growth of rate in urban population is the natural consequence of modernization and industrialization to which we are committed. "Search for security of life and property, greater employment opportunities, better amenities of life and just glamour are the main factors responsible for this exodus from rural to urban areas." This growing urbanization has affected not only economic structure of the country but also its 'social and cultural profiles'.
\end{abstract}

Keywords: village republics', urbanization , industrialization Urban Local Bodies

\section{Introduction Municipal Government}

Some of the striking features of municipal government are as follows; ${ }^{1}$ Firstly, municipal government is a territorially restricted non- sovereign political institution having a population for whose exclusive welfare it is intended and instituted. It exclusively concerns itself with the amenities and services which are enjoyed by the inhabitants of its own area.

Secondly, municipal government is a creature of the state or central legislature as the case may be. As such, it has no inherent powers of its own except those granted by a superior authority. Thus, its powers are derivative, not original. It has to regulate its affairs under external vigilance. In fact, the area and form of government, the term and size of council as also the powers, functions, staff pattern, autonomy and financial resources..........these and such other relevant matters are determined in the legislative enactments of the legislature. In short, it has to live and grow in accordance with the directions of the same authority.

Thirdly, municipal government is self-government in the sense that it is a government of the people of the town or city represented by the councilmen elected directly from different wards into which the municipal area is divided for electoral purpose and governed for the well being of all sections of the civic community. Thus, it is in this area that Abraham Lincoln's observation of what is democracy is most accurate and acceptable. Municipal government is a government on the spot. It is a representative government runs on democratic lines. It is needless to mention that real democracy is found in theory and practice in municipal self-government.

Fourthly, municipal government is an autonomous body enjoying freedom of action in matters of internal administration. It possesses the legal right and an organization to regulate its own affairs. This, as Robson observes, "in turn, presupposes the existence of a local authority with the power to act independent 
of external control as well as participation of the local community in the administration of its own area". In other words, municipal government is absolutely free to manage its affairs within the limits specified in the municipal laws.

Fifthly, municipal government is based on the philosophy that it is a government of the locality and as such it shall be supported financially by the people of the locality. As such, it is the trustee of the people and is intended for their welfare. It possesses the legal power to raise money through a variety of tax and non-tax sources and remunerative enterprises and receives grants-in-aid from the state, centre and other agencies. It also raises loans from the government and financial institutions. The amount thus accrued, will be spent on the overall development of the entire municipal area. Thus, municipal government has great status as well as responsibility in the governmental system of the nation.

Sixthly, municipal government is a corporate body and possesses a collective legal personality of its own apart from the particular and separate personalities of its constituent citizens. ${ }^{2}$ It can sue and be sued in a court of law. It can acquire, hold, transfer and dispose of property of any kind. It has a common seal which gives validity to all its documents.

\section{Need for Municipal Government}

The need for municipal government arises from the fact that it is a government of a particular town, city or metropolitan area and its needs differ from town to town, city to city and from one metropolitan area to another. The needs and problems of a port based city like Visakhapatnam would be different from the garden city of Bangalore. The city of Mumbai which is situated on an island differs in its needs from the city of Calcutta located on the banks of river Hooghly or the city of Madras which remains on a flat area touching the waves of the bay. As such every city has its own problems some of which defy solution and needs a government of its own to understand, and meet its requirements and also solve its problems from the experience of its own existence and evolution as also from the experience of other cities. In this context, it may be observed that the needs of different sections of the civic community are better understood and better sorted out by the people and their representatives. The government at the union and state levels may not be in a better position to understand the complex and complicated local issues which differ from city to city in a large measure. As observed by S.R. Maheswari, in taking up the problems, knowledge of local conditions and environment is necessary. The basic concept of local government, as he thinks, springs from these requirements. Some of the functions of a government, whether central, regional or local, are local in their intensity, character and scope. These functions are not common to all the areas and the degree of their intensity shows marked variations from region to region. As such, problems arising out of these functions are better sorted out locally. ${ }^{3}$

\section{Purpose of Municipal Government}

The purpose served by municipal government in a democratic state like India is very great not only on account of the services it renders for the common welfare of the civic community but also on account of the opportunities it places before men and women for free, active and intelligent participation in the government of their area.

\section{Need for Municipal Government}

The need for municipal government arises from the fact that it is a government of a particular town, city or metropolitan area and its needs differ from town to town, city to city and from one metropolitan area to another. The needs and problems of a port based city like Visakhapatnam would be different from the garden city of Bangalore. The city of Mumbai which is situated on an island differs in its needs from the city of Calcutta located on the banks of river Hooghly or the city of Madras which remains on a flat area touching the waves of the bay. As such every city has its own problems some of which defy solution and needs a government of its own to understand, and meet its requirements and also solve its problems from the experience of its own existence and evolution as also from the experience of other cities. In this context, it may be observed that the needs of different sections of the civic community are better understood and better sorted out by the people and their representatives. The government at the union and state levels may not be in a better position to understand the complex and complicated local issues which differ from city to city in a large measure. As observed by S.R. Maheswari, in taking up the problems, knowledge of local conditions 
and environment is necessary. The basic concept of local government, as he thinks, springs from these requirements. Some of the functions of a government, whether central, regional or local, are local in their intensity, character and scope. These functions are not common to all the areas and the degree of their intensity shows marked variations from region to region. As such, problems arising out of these functions are better sorted out locally. ${ }^{3}$

\section{Purpose of Municipal Government}

The purpose served by municipal government in a democratic state like India is very great not only on account of the services it renders for the common welfare of the civic community but also on account of the opportunities it places before men and women for free, active and intelligent participation in the government of their area.

\section{Review of Literature}

Review of literature is the most important aspect in any research work. It is a measure stating the recent output on a particular area of research and organized in a helpful sequence to strengthen the present research techniques. The main objective of the review of literature is to understand the research activities that have taken place in a particular discipline in general and in the area of research in particular. A review of literature of related to the functioning of urban local self governments in general and finances of local self governments in particular. Thus, the review covers studies made at international and national level.

Bhardwaj R.K. (1970) ${ }^{9}$ in his paper discuss the causes of backwardness of municipal bodies In India. He expresses his dissatisfaction in the following words. The way in which the people have dealt with the local bodies in India does not bring credit to the smooth functioning of municipal administration.

Ali Ashraf $(1977)^{\mathbf{1 0}}$ in his paper made a focus on the functioning of urban local bodies in three big cities namely, Calcutta, Kanpur and Ahmadabad. The main objective of the study was to understand the nature of local government in these three cities and their capacity to manage civil problems. The major focus of the study is on the political questions, the recruitment of civil leaders and municipal employees. The local political systems in these three cities, can be seen to represent values and interests that affect the management of civil problems differently in different cities, Asharaf concludes, garbage the morale and service conditions of the employees, the performance on each of these items is satisfactory in Ahmedabad unsatisfactory in Kanpur.

Om Prie Srivastava's (1980) ${ }^{\mathbf{1 1}}$ explain the various kinds of state control and suggest remedial measures that need to be taken. The author has felt that government should reorient its attitude in regard to municipal corporations, providing constructive guidance and adequate assistance to them, as an active partner in the common cause of city administration.

\section{Objectives of the study}

The major objectives of the present study are as follows.

1. To study the historical evolution and growth of urban local self governments in India.

2. To examine different financial wherewithal of urban local self governments in India.

3. To study the socio-economic and demographic profile of the Kurnool Municipal Corporation.

4. To analyze the income and expenditure pattern of Kurnool Municipal Corporation.

5. To suggest various measures for the financial strengthening of urban local bodies in general and in Andhra Pradesh in particular.

\section{Hypotheses}

1. The share of both capital income as well as capital expenditure of Kurnool Municipal Corporation is showing downward trends.

2. The total amount spent by the Kurnool Municipal Corporation's never exceeds the Income of the Corporation.

\section{Methodology}

The Municipal Corporation of Kurnool in Rayalaseema region in Andhra Pradesh has been selected for the purpose of the present study. The study covers a 10 year period from 2007-08 to 2016-17. As the 
pre 2007-08 data is not properly available in respect of various resources and expenditure items of Kurnool Municipal Corporation, the year 2007-08 has been chosen as the initial year of the study. However, for examining the trends in the finances of Municipalities in the state of Andhra Pradesh as a whole, some selected years have been observed on the basis of the availability of data in Andhra Pradesh for general analysis of various financial resources and the items of expenditure of Municipalities.

\section{Sampling Design}

The study area is selected on the basis of purposive sampling method. For this purpose, Kurnool Municipal Corporation in Kurnool district which is located in a drought prone Rayalaseema region of Andhra Pradesh has been selected for the purpose of the study.

\section{Sources of Data}

The data required for the study has been collected from the office of the Municipal Corporation, Kurnool. The researcher personally collected the data from the records of the concerned sections of the Municipal Corporation. Besides, data has been collected from the Reports of Ministry of Urban Development, Government of India, National Institute of Urban Affairs, (NIUA), New Delhi, Directorate of Economics and Statistics, Government of Andhra Pradesh, Hyderabad and from the Census Reports and the reports Directorate of Municipal Administration, Andhra Pradesh etc. All these data has been a very useful source of information on different aspects of Municipal finances in Andhra Pradesh in general and the selected Municipal Corporation of Kurnool in Rayalaseema region in particular.

\section{Statistical Tools}

The data has been rigorously analysed and presented in order to arrive logical conclusions. The simple statistical tools like averages, growth rate, per cent etc have been employed to analyse the various financial resources and functional expenditure pattern under various facets of selected Kurnool Municipal Corporation. The bar and pie diagrams and the time series analysis graphs have been drawn wherever necessary.

\section{Plan of the Study}

The study is divided into seven chapters.

Chapter-I-Introduction and Methodology- presents the background of the study. To understand the nature of the problem of municipal finances a thorough review of literature has been done in this chapter. The review covers international, national and regional studies on the finances of urban local governments. It also contains objectives, methodology, data collection, data analysis, outline of the study etc.

The second chapter- Historical Evolution and Growth of Urban Local Governments- is devoted to examine the origin and growth of urban local self governments at national and state level.

The third chapter- Financial resources of Urban Local Self Governments in India- critically examines the financial resources of urban local bodies in India in general and in Andhra Pradesh in particular.

The fourth chapter- The Setting- elaborates the geographical, demographic and municipal profile of Kurnool Municipal Corporation.

The fifth Chapter- The trends in the Receipts of Kurnool Municipal Corporation- analyses various income resources and trends in the flow of revenues of Kurnool Municipal Corporation during 20072008 to 2016-2017.

The sixth chapter- The trends in the Expenditure Pattern of Kurnool Municipal Corporationanalyzes the expenditure pattern of Kurnool Municipal Corporation during 2007-2008 to 2016-2017. conclusion.

The last chapter -Summary and Conclusion-is entirely devoted for the summary of findings and 


\section{Categories of Receipts of Urban Local Bodies}

A government levies, collects and appropriates taxes, duties, tolls, fees and cesses; it gets net proceeds of certain taxes/duties collected by government of another level; it can get a share in proceeds of certain other taxes/ duties, again collected by government of another level; it usually receives general and specific grants from other governments and other bodies, besides donations/contributions by individuals; and it can receive property incomes and interest on loans made people, other governments or its own corporate enterprises. For utility services it can demand user charges. It can also raise loans. For the utility services such as water, it can demand user charges. It does receive some revenue for regulatory and administrative activities in terms of fees, fines and penalties but they are neither nor should be turned into revenue-raising propositions. The receipts in case of an urban local body may broadly be categorized as:

a) Tax Revenue Receipts from (i) its own taxes, (it) assigned taxes and (in) shared taxes;

b) Non-Tax Revenue Receipts: (i) property income in terms of rent, royalty, interest, and profits/dividends, (n) user charges for public utility services such as water, electricity; and (nz) fees (like license fees), fines and penalties;

c) Grants: (i) in lieu of withdrawn taxes, (n) in aid of revenue to meet the shortfall in revenue (general grant) or in aid of certain desirable activities; and

d)Loans for particular project or for any purpose.

Table 5.1

Total Revenue Receipts of Kurnool Municipal Corporation

\begin{tabular}{|c|c|c|c|}
\hline S. No & Year & Amount Received & Growth Rate \\
\hline 1 & $2007-08$ & $7,405.77$ & - \\
\hline 2 & $2008-09$ & $7,807.56$ & 5.43 \\
\hline 3 & $2009-10$ & $9,018.13$ & 15.51 \\
\hline 4 & $2010-11$ & $12,218.99$ & 35.49 \\
\hline 5 & $2011-12$ & $10,948.36$ & -10.40 \\
\hline 6 & $2012-13$ & $17,338.16$ & 58.36 \\
\hline 7 & $2013-14$ & $12,955.31$ & -25.28 \\
\hline 8 & $2014-15$ & $14,137.46$ & 9.12 \\
\hline 9 & $2015-16$ & $17,496.61$ & 23.76 \\
\hline 10 & $2016-17 *$ & $28,475.45$ & 62.75 \\
\hline
\end{tabular}

Source: Budget and Revised Estimates of Kurnool Municipal Corporation for the Respective Financial Years

\section{* Budget Estimates}

The data in table 5.1 shows that the total receipts of Kurnool Municipal Corporation is increasing year by year except in 2 financial years i.e. 2011-12 and 2013-14. Accordingly positive growth rate in total receipts of Kurnool Municipal Corporation is registered in 8 out of 10 years of study. The highest positive growth rate of 62.75 per cent is registered in 2016-17. In 2007-08 the total receipts of Kurnool Municipal Corporation stood at Rs. 7, 405.77 lakhs and they enhanced to Rs. 28, 475.45 lakhs by 2016-17. It means that during 10 years of study the total receipts increased more than 3 times.

Table 5.2

Year Wise Total Revenue Receipts of Kurnool Municipal Corporation

\begin{tabular}{|c|c|c|c|c|}
\hline S. No & Year & Amount Received & Growth Rate & $\begin{array}{c}\text { Share in Total } \\
\text { Receipts }\end{array}$ \\
\hline 1 & $2007-08$ & 3684.25 & - & 49.75 \\
\hline 2 & $2008-09$ & 3971.73 & 7.80 & 50.87 \\
\hline 3 & $2009-10$ & 5084.02 & 28.01 & 56.38 \\
\hline 4 & $2010-11$ & 8096.73 & 59.26 & 66.26 \\
\hline 5 & $2011-12$ & $7,811.71$ & -3.52 & 71.35 \\
\hline
\end{tabular}




\begin{tabular}{|c|c|c|c|c|}
\hline 6 & $2012-13$ & $10,469.43$ & 34.02 & 60.38 \\
\hline 7 & $2013-14$ & $9,421.13$ & -10.01 & 72.72 \\
\hline 8 & $2014-15$ & $10,708.57$ & 13.67 & 75.75 \\
\hline 9 & $2015-16$ & $13,300.11$ & 24.20 & 76.02 \\
\hline 10 & $2016-17 *$ & $16,660.45$ & 25.27 & 58.51 \\
\hline
\end{tabular}

Source: Budget and Revised Estimates of Kurnool Municipal Corporation for the Respective Financial Years

* Budget Estimates

It is evident from table 5.2 that the total revenue receipts of Kurnool Municipal Corporation are gradually increasing except in 2011-12 and 2013-14. The revenue receipts of the Kurnool Municipal Corporation in 2007-08 are Rs. 3684.25 lakhs in 2007-08 and they bulged to Rs. 16,660.45 lakhs by 2016-17 registering more than 4 times increase in 10 years of study. The share of revenue receipts is total receipts is also growing gradually except in 2012-13 and 2016-17. In 2007-08 the share of revenue receipts is less than half of total revenue receipts. But, by 2015-16 the share of revenue receipts increased to 76.02 per cent. Negative growth rate in total revenue receipts of Kurnool Municipal Corporation is registered in 2 out of 10 years of study.

\section{The Trends In The Expenditure Pattern Of Kurnool Municipal Corporation}

The urban local bodies spends(both capital and revenue expenditure) on infrastructure and services such as water supply, sewerage system, solid waste treatment and disposal, storm water drainage, city-wide roads, and street lighting. Table 6.1 gives the clear picture of total expenditure incurred by Kurnool Municipal Corporation during 2007-08 to 2016-17.

Table 6.1

Total Expenditure of Kurnool Municipal Corporation

(Rs. In Lakhs)

\begin{tabular}{|c|c|c|c|}
\hline S. No & Year & Amount Spent & Growth Rate \\
\hline 1 & $2007-08$ & 3965.36 & - \\
\hline 2 & $2008-09$ & $4,276.19$ & 7.84 \\
\hline 3 & $2009-10$ & $8,195.30$ & 91.65 \\
\hline 4 & $2010-11$ & $10,032.01$ & 22.41 \\
\hline 5 & $2011-12$ & $9,993.76$ & -0.38 \\
\hline 6 & $2012-13$ & $14,476.22$ & 44.85 \\
\hline 7 & $2013-14$ & $12,891.53$ & -10.95 \\
\hline 8 & $2014-15$ & $13,877.20$ & 7.65 \\
\hline 9 & $2015-16$ & $17,052.60$ & 22.88 \\
\hline 10 & $2016-17 *$ & $28,216.00$ & 65.46 \\
\hline
\end{tabular}

Source: Budget and Revised Estimates of Kurnool Municipal Corporation for the Respective

Financial

$$
\begin{aligned}
& \text { Years. } \\
& \text { * Budget Estimates. }
\end{aligned}
$$

Table 6.1 makes it clear that the total expenditure incurred by Kurnool Municipal Corporation is showing upward trends except 2011-12 and 2013-14. The total expenditure incurred by Kurnool Municipal Corporation in 2007-08 is Rs. 3, 965.36 lakhs and they rose to Rs. 28, 216 lakhs by 2016-17. It denotes that during 10 years of study the total expenditure of Kurnool Municipal Corporation increased more than 7 times. With regard to growth rate highest and lowest positive growth rates were registered 2008-09 and 2014-15 respectively. On the other hand negative growth rate in total expenditure is registered in 2011-12 (0.38 per cent) and 2013-14 (-10.95 per cent).

Figure- 5.1 
Total Revenue Receipts of Kurnool Municipal Corporation

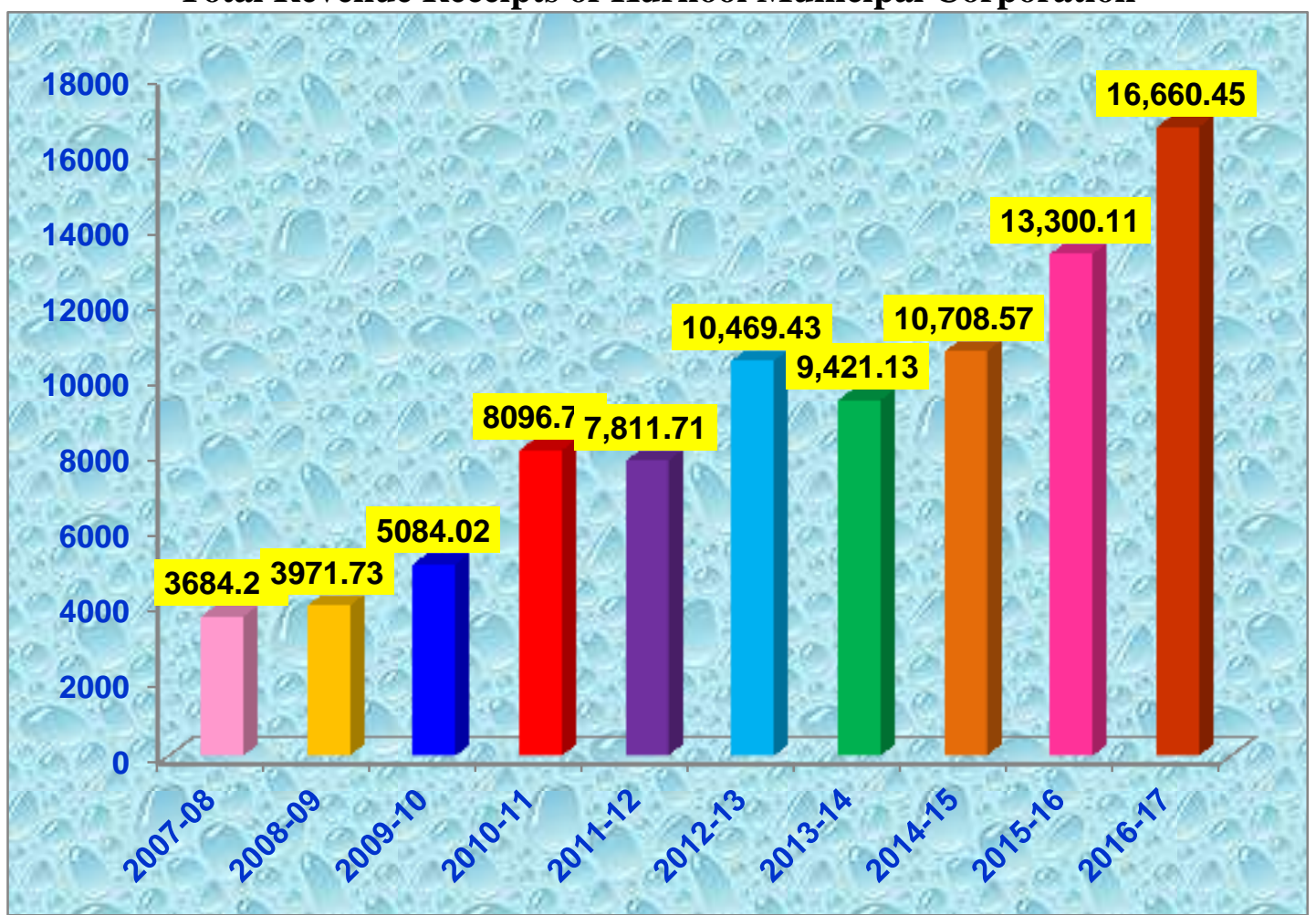




\section{Summary and Conclusion}

Urbanization is perceived as a determinant, as well as a consequence of economic development. Over the past two decades, many countries in Asia have experienced rapid economic growth. This has led to a rapid rise in their urban population. However, in spite of a significant increase in national wealth and personal incomes, the quality of life of an average urban resident is not satisfactory. Urban centers are characterized by squalor slums, traffic congestion, and shortages of water and power. While the national governments pursue the goals of economic development, it is generally left to the local governments to manage rapidly growing urban areas, and provides for basic services to the residents.

Urban management and governance has assumed an increasing importance, as the capacity of a nation to pursue its economic goals is contingent upon its ability to govern the cities. This is largely due to the significant contribution of the urban centers to the national income. The economic liberalization and decentralization of government have been the most common features of developmental policies of most countries in the past decade. Nations have evolved policies, aimed at achieving high economic growth rates, integrating the national economy with the global one and increasing economic efficiency through greater competition. At the same time, decentralization polices, aimed at delegation, devolution and democratization have also been pursued. The emergence of these trends has a profound implication on urban management. In the general discussion of macroeconomic policies, the role of urban economies is not well recognized. The macro policies often have an anti-urban bias and the national governments have pursued programmes which restrict the growth of large cities, reduce migration to cities, and achieve a "balanced urban pattern". It is only now that the role of city economies in national development has been understood. It is seen that in a global economy, there is an increasing competition among cities to attract cross-border investments.

The ability of a city to attract global investments largely determines the extent of investments in a nation. While the national governments are involved in macro policy formulations, it is left to the local government to provide for the necessary infrastructure and services to attract such an investment. Municipal authority in India was as old as Indus civilization of 3000 BC. But, as a political institution, it is totally British in its origin and fame. The first (Municipal) Corporation was established in 1688 in the port town of Madras. Subsequently, Corporations were established in Bombay and Calcutta during the year 1726. The next milestone in municipal administration is Lord Mayo's Resolution of 1870. Lord Mayo realized the need for popular association in civic functions. He conceived this in a broader setting of decentralization and as a measure of self-governance at the local level.

World over, cities are the central drivers of growth; they are the leading edge of economic dynamism. However, the extent to which cities fulfill this role by promoting competition, galvanizing innovation and accelerating growth depends critically on the nature and adequacy of urban governance and finance. Adequate finance is necessary to ensure satisfactory standards of infrastructure and services; governance systems determine not only the allocative and technical efficiency of spending but also the responsiveness and accountability with which services are actually delivered. Thus, good policies, efficient and responsive local governance systems and sound arrangements to finance public services are critical elements in sustainable urban development. They shape the nature and quality of public services provided, as well as the structure of incentives and accountability.

Financing urban infrastructure and services adequately is a formidable challenge. The infrastructure deficit in urban areas is not only large but growing. In contrast, the resources available to urban local governments are scant. With respect to financing urban infrastructure, development charges should be used more effectively and more should also be done to utilise public lands more effectively. In addition, to a considerable extent capital expenditure requirements will have to be financed through borrowing. Development of the municipal bond market is, therefore, an important area where much remains to be done. Credit rating municipal governments, encouraging them to undertake reforms, and ensuring hard budget constraints are all important for developing a healthy bond market. Another important area is to encourage public private partnerships. The paper points out some successful cases of PPPs which have helped to augment water supply and solid waste management in municipal bodies. It is important to involve the private sector in the provision of urban services to the extent feasible to ensure efficiency and accountability. 
Reform of urban governance and finance are critical not only to improving the quality of life of the people living in urban areas but also to ensure that cities, and especially the large metropolitan areas, become the drivers of economic growth in the country. Ensuring adequate availability of finances and improving governance is an imperative, and the rate at which urbanisation is taking place makes it urgent than reform initiatives must be undertaken. If India is to expand its national rate of economic growth significantly, concerted action to reform both urban policies and urban initiatives are required soon.

With this background the present attempts to study the revenue and expenditure pattern of Kurnool Municipal Corporation of Andhra Pradesh. The study is mainly confined to Kurnool Municipal Corporation as it is the oldest municipality in the district. The study deals with the various sources of income to the Kurnool Municipal Corporation and the expenditure incurred by the municipality for the public and other purposes. The study examines whether the income sources of the municipality is stable over the years or not. The study examines the role of Kurnool Municipal Corporation in enhancing the basic infrastructure facilities and other services to the public in its territorial jurisdiction. .

The data required for the study has been collected from the office of Kurnool Municipal Corporation. The researcher personally collected the data from the records of the concerned Municipality. Some more data has been collected from the Directorate of Economics and Statistics, Government of Andhra Pradesh, Hyderabad and from the Census Reports and the Municipal Directorate of Andhra Pradesh, Hyderabad has been a very useful source of information on different aspects of Municipal finances in Andhra Pradesh in general and the selected Kurnool Municipal Corporation in Rayalaseema region in particular. The chapter wise summary of the study in narrated hereunder.

In the first chapter as stated, it is summarized with the following objectives and hypothesis.

\section{Objectives of the Study}

The specific objectives of the present study are as follows:

1. To discuss the genesis and growth of urban local governments in India with particular reference to Andhra Pradesh.

2. To examine the changes brought out by $74^{\text {th }}$ Constitutional Amendment in the functioning of urban local bodies.

3. To discuss the socio-economic and political profile of Kurnool Municipal Corporation.

4. To compare and analyze the financial performance in terms of revenue and expenditure of Kurnool Municipal Corporation.

5. To analyze the income and expenditure pattern of Kurnool Municipal Corporation.

6. To make suitable suggestions for the enhancement of financial resources of urban local bodies.

In the second chapter the researcher has studied the evolution and growth of urban local self governments in India as well as Andhra Pradesh. The chapter also presents the brief history and present status of Kurnool Municipal Corporation. The developments in the evolution and growth of urban local governments in ancient, medieval and modern periods in India are covered in this chapter. Special focus is made on the developments in the growth of urban governments during colonial rule. As part of it the chapter discusses at length the Lord Rippon resolution, Royal Commission, Morley-Minto Reforms of 1909, Montague-Chelmsford, Government of India Act 193 etc. the chapter makes a comprehensive analysis of $74^{\text {th }}$ Constitutional Act and its implications on the functioning of urban local governments in India. With regard to municipal governments in Andhra Pradesh, the chapter discusses the features of Andhra Pradesh Municipalities Act 1965, Andhra Pradesh Municipalities Law (Amendment Bill), 1986, Andhra Pradesh Municipal laws Amendment Act, 1994. The chapter also covers the issues like classification of municipalities in Andhra Pradesh, criteria for classification of municipalities, strength of Municipal Councils, details of reservation system at state level etc. with regard to Kurnool Municipal Corporation, the study makes an overview of Kurnool town, location, characteristics and commercial importance of the town. The demographic profile of Kurnool town as per 2011 Census and religious composition of population, slum population and poverty among slum dwellers is also covered in this chapter. The political setup of Kurnool Municipal Corporation and party wise and social category wise elected members of Kurnool Municipal Corporation in 2014 elections is also analyzed in this chapter. 
The third chapter is devoted to study the financial resources of urban local bodies. As a part of it the chapter examines the distribution of taxes between the Centre, States and Urban Local Bodies (ULBs), conventional sources of ULB revenue and need for promoting the model practices of ULB financial management. The chapter also discusses the various revenue sources of ULBs like user charges, local taxation, general grants, specific purpose grants, borrowings, development charges, intergovernmental transfers, proceeds from sale of land and buildings, public-private partnerships and Municipal Bonds etc. The financial measures for local bodies under different Five Year Plans from $1^{\text {st }}$ to 12 th Five Year Plan were also covered in this chapter. The Role of Union Finance Commissions in strengthening ULB finances, grants recommended under different Finance Commissions and major recommendations of XIV Finance Commission with regard to urban local bodies were also discussed in this chapter.

The fourth chapter analyzes the trends in the revenue of Kurnool Municipal Corporation during 2004-05 to 2013-14. Item wise revenue received by Kurnool Municipal Corporation like revenues from property tax, rent of shop / buildings, non plan grant, surcharge on stamp duty, entertainment tax , fines \& penalty, advertisement tax, market fees, water supply tax, development charges, building license fees , encroachment charges, betterment charges, layout fees, layout conversion fees, miscellaneous sources, secondary school fees, school building rent, birth \& death certificate fees, new taps from people deposits, grants for running upper primary, teaching grant in aid, government road grants, government grant and $\mathrm{mp}$ grants, school buildings grant, drought relief grants, drainage grant, SJSRY grants, State Finance Commission grants, State Finance Commission adjustment grants, park and play ground grants, APUR MSP grants, library cess etc.

In the fifth chapter an attempt is made analyze total expenditure incurred by Kurnool Municipal Corporation, expenditure on public works - roads, construction of toilets, street lights and electricity charges, expenditure incurred on drinking water supply, expenditure incurred on drainage office maintenance, fogging and prevention of malaria, sanitation (white wash \& bleaching powder), expenditure on drawing vehicles and their maintenance contract labour, the maintenance of maternity centre, contingency expenditure, miscellaneous expenditure, expenditure for the repairs of primary school buildings, on the Payment of M.V. Taxes, Municipal Hospitals, on the repair of office building, office building construction, expenditure on APURIMSP, Expenditure on LIC, expenditure on retired employees provident fund ,expenditure on deposits and advance, expenditure on Professional Tax APGIS GILIS, expenditure on Kurnool Municipal Corporation chairman transport, expenditure on law charges, expenditure on daily news papers, expenditure incurred for capture of on dogs, pigs, monkeys, expenditure on public health workers uniform, expenditure incurred on garbage vehicles, expenditure on town planning section law fees, expenditure on mobile and telephone charges, expenditure on AV number plates, expenditure on books and forms, expenditure on survey, expenditure on advertisement in daily papers, expenditure on car rent, expenditure on jeep and tractor purchase and maintenance, expenditure on secondary education , expenditure on primary education, expenditure from MPLADS etc.

In the sixth chapter an attempt is made to present summary of the study conclusions major findings and suggestions.

\section{Findings of the study}

* It is evident from the study that the total revenue of Kurnool Municipal Corporation is erratically distributed over the years. During first four years of study it gradually increased year by year. In 2008-09 it sharply fall down and further declined in the next year. But after that it again gradually increased up to 2014-2015.

* It is clear from the study that the property tax shares in the total revenue of Kurnool Municipal Corporation showing downward trend from 2009-10 onwards. The share property tax in total revenue of municipality is highest in 2008-2009 and lowest in 2013-2014.

* It is clear from the study that the share of revenue from shops/ buildings to total revenue of the municipality is gradually increasing except 2007-2008 and 2013-2014.

* The study reveals that there are wider fluctuations in the non-plan grants received by the Kurnool Municipal Corporation during the study period. But in the last year of study i.e. 2013-2014, highest non plan grants of Rs. 14,650,000 were received by the Kurnool Municipal Corporation. 
* The study shows that the share of surcharge on stamp duty in total revenue of Kurnool Municipal Corporation is not evenly distributed over the years. Its share in 2007-2008 financial years is only 2.60 per cent of total revenue and highest (9.80 per cent) in 2012-2013. 2 out of 10 years registered negative growth rate in the collection of surcharge on stamp duty in Kurnool Municipal Corporation.

* It is clear from the study that the share of entertainment tax in the total revenue of Kurnool Municipal Corporation never crossed 2 per cent of total revenue.

* As per the study the share of revenue from fines and penalties in Kurnool Municipal Corporation is less than 1 per cent to total revenue during 9 out of 10 years of study.

* It can be noted that the revenue receipts of Kurnool Municipal Corporation under the head of advertisement tax registered 9 years of positive growth.

* The study shows that the revenue received by Kurnool Municipal Corporation under the head of market fees is gradually increasing from 2007-08 onwards. The share of market fees revenue to total revenue of the Municipality is high (2.09 per cent) in 2011-12 and low (0.74 per cent) in 2007-2008.

* It can be inferred from the study that water tax seems to be one of the important sources of income to the Kurnool Municipal Corporation. Its share to total revenue of municipality is also showing positive from 2007-2008 onwards with some exceptions. During 10 years of study the income from water tax increased more than 3 times.

* The revenue from developmental charges ranges between Rs.2,50,000 to Rs.7,00,000 during the study period.

* As per the study the receipts of Kurnool Municipal Corporation by issuing licenses to buildings is distributed unevenly. The highest amount of Rs.1, 20, 00,000 has been collected in 2011-12 and the lowest amount of Rs.3, 00,000 was collected in 2008-09.

* The study indicates that the revenue collected by Kurnool Municipal Corporation under the head of encroachment charges showing downward trends from 2007-08 to 2011-12.

* The study shows that the revenue from betterment charges in Kurnool Municipal Corporation showing more up and downs. In 2005-06, 2010-11 and 2013-14 there is a sharp increase in the revenue through betterment charges. On the other hand sharp decline in the receipts is registered in 2008-09.

* It can be found from the study that the amount collected by Kurnool Municipal Corporation under the head of birth and death certificate fees is erratically distributed. The highest amount of Rs.4,50,000 was collected in 2012-13. On the other hand lowest amount of Rs.1,10,000 was collected in 2004-05.

* It is clear from the study that the revenue from new tap connection is gradually increasing except 2005-06 and 2007-08. It means that the people in municipal area recognized the importance of protected water for household consumption.

* The study shows that the grants released by Union and State Governments to Kurnool Municipal Corporation for running primary and upper primary schools and teaching grants sharply decreased from 2009-10 onwards the State Government brought all primary and upper primary schools under one umbrella.

* The study reveals that in 2010-11 the Kurnool Municipal Corporation received highest amount i.e Rs.143, 190,00 of grants for laying the roads in municipal areas. In 2012-13 the Municipality received only Rs.256, 50,00 as road grants, which is lowest in 10 years of study.

* It is evident from the study that there are wide variations in the Government and MP grants received by Kurnool Municipal Corporation during 10 years of study.

* As per the study, the Kurnool Municipal Corporation received highest amount of Rs.8, 253,000 in 2010-11. On the other hand in 2006-07 the municipality received lowest amount of Rs.1, 5000,000 under the head of drought relief grants. The highest growth rate of 121.53 per cent in the drought relief grants is registered in 2009-10.

* There are several up and downs in the volume of drainage grants received by Kurnool Municipal Corporation over the years. The highest growth rate of 1659.70 per cent in the drainage grants is registered in 2009-10. The value of amount under drainage grant is more than Rs. 2 crores in 2012-13 and 2013-14. 
* The SFC adjustment grants received by Kurnool Municipal Corporation are constant during last three years of study. The share of SFC adjustment grants to total revenue ranges between 0.63 per cent (2013-14) to 5.03 per cent (2005-06).

* It can be inferred from the study that the grants received by Kurnool Municipal Corporation in the form of park and play ground is fluctuating between Rs.500, 000 (2009-10) to Rs.30, 00,000 (200506).

* It is clear from the study that the grants received by Kurnool Municipal Corporation under APURMSP are not evenly distributed over the years. The share of APURMSP grants to total revenue of municipality is 4.48 per cent and 4.04 per cent in 2006-07 and 2010-11 respectively.

* The study reveals that the total expenditure incurred by Kurnool Municipal Corporation is not evenly distributed over the years. Negative growth rate in expenditure pattern is registered in 3 out of 10 years of study. Positive growth rate in expenditure is registered in 7 out of 10 years of study.

* It is clear from the study that the percentage of expenditure incurred on public works to total expenditure showing downward trends except 2009-10.

* The actual amount sanctioned by Kurnool Municipal Corporation for the construction of toilets is gradually increasing from 2004-05 to 2009-10 and the highest amount of Rs.800,000 was sanctioned in 2011-12. But the share of toilet construction expenditure to total expenditure is less than half percent during 2004-05 to 2010-11.

* The study indicates that the expenditure incurred by Kurnool Municipal Corporation on street lights and electricity is not evenly distributed over the years. In 2009-10, the municipality spent highest amount of Rs.65, 00,000 for providing street lights. In the same way the share of street light and electricity expenditure to the total expenditure of Municipality is high i.e. 5.76 compared to other years.

* It is evident from the study that the expenditure incurred by Kurnool Municipal Corporation is on drinking water is gradually increasing except 2007-08 and 2009-10. The expenditure sharply increased in 2011-12 and 2012-13.

* It can be inferred from the study that the expenditure incurred by Kurnool Municipal Corporation on drainage is negligible up to 2010-11. It slightly increased afterwards.

* As per the study the expenditure incurred by Kurnool Municipal Corporation on stationary and printing ranges between Rs.75, 000 (2009-10) to Rs.12, 30,000 (2012-13). The share of stationary and printing expenditure total expenditure varies between 0.07 per cent to 0.90 per cent.

* The actual amount incurred by the Kurnool Municipal Corporation on fogging showing upward trends expenditure incurred by municipality on fogging and pollution of Malaria increased more than 9 times.

* It can be found from the study that the expenditure over the years. No expenditure on sanitation (white was \& bleaching powder) was incurred in 2009-10 and 2010-11.

* The study reveals that the expenditure on drawing and maintain vehicles is sharply increased from 2010-11 onwards. During 10 years of study the expenditure on drawing and maintenance of vehicles is increased nearly 8 times.

* It is clear from the study that the expenditure incurred on contract labour is gradually increasing during 10 years of study. The expenditure on contract labour increased more than 16 times during the study period.

* It is regrettable to note that the Kurnool Municipal Corporation has not spared even single rupee for the maintenance of maternity centre from 2007-08 onwards.

* It can be inferred from the study that the Kurnool Municipal Corporation has not spent any amount for the repair of Primary school buildings in 2004-05. There after also there are wider variations in the amount spent for the repairs of primary schools buildings.

* It is evident from the study that the expenditure incurred by Kurnool Municipal Corporation for the maintenance of municipal hospitals is showing upward trends from 2011-12 onwards. 3 out of 10 years of study registered negative growth rate.

* It is clear from the study that the total amount spent for the repairs of office building gradually increased from 2005-06 to 2007-08 and thereafter it sharply declined. In 2011-12 and 2012-13 once again the expenditure for the repairs of office building increased sharply. 
* It is evident from the study that these are wider variations in the amount allocated for the construction of new office building. The amount allocated for the construction of new office building ranges between Rs.10, 00, 00 (2007-08) to Rs.1, 72, 73,726 (2006-07).

* The share of expenditure on APURIMSP to total expenditure fluctuating between 1.09 per cent to 11.21 per cent. Negative growth rate in the expenditure incurred on APURIMSP is registered in 4 out of 10 years of study.

* It is clear from the study that the expenditure incurred on LIC by Kurnool Municipal Corporation is erratically distributed over the years. The total amount of expenditure incurred ranges between Rs.10, 00,000/- Rs.70, 00,000/-.

* It is evident from the study that the expenditure incurred by Kurnool Municipal Corporation on deposits and allowances is gradually increasing except 2007-08 and 2013-14. Highest allocations of Rs.97, 85,440 were made in 2012-13 and lowest allocations of Rs.13, 50,000 were made in 2004-05.

* The study shows that the expenditure incurred by Kurnool Municipal Corporation on garbage vehicles varies between Rs.2, 63,000 to Rs.7, 41,333. But, the expenditure incurred over the years is not evenly distributed over the years.

* It can be inferred from the study that there are wider variations in the expenditure incurred on advertisement in local dailies. Such expenditure varies between Rs.50,000 (2007-08) to Rs.26,05,861 (2006-07). Except 2006-07 and 2010-11 the share of expenditure on advertisements in dailies to the total expenditure of Kurnool Municipal Corporation is less than 1 per cent.

\section{Recommendations}

A municipal finance list shall be included in the constitution through amendment to provide assured and sustainable sources of income to the ULBs.

$*$ Property tax reforms like periodic revision, strengthening assessment, levy and collection procedures, improving billing and collection efficiency, elimination of exemptions, provision of penal clauses on illegal constructions, identifying un-assessed and under-assessed properties, etc., should be prioritized by ULBs to improve their finances and to mobilize more resources.

$\leftrightarrow$ The user charges should be revised periodically by linking them to service improvements.

The inefficiencies in internal revenue mobilization is an area of concern and the ULBs should address this on a priority. The ULBs should exploit all the untapped sources which municipal Acts empower them. The internal mobilization will, to some extent, bridge the finance gap and allow them the functional autonomy.

* The GoI should give effect to the decision taken on raising the ceiling on profession tax as this source has potential in all states to mobilize additional revenues. Efforts should be made by the state governments to enforce the laws relating to profession tax. The states may lake a leaf from the Gujarat, Kerala and Tamil Nadu practices.

The state government should exploit entertainment tax effectively through improved methods of levy and collection.

$\leftrightarrow$ The state governments should remove the restrictions on the borrowing powers of the ULBs and give them the freedom based on their credit rating to mobilize resources.

$\leftrightarrow$ Credit rating of ULBs should be made mandatory at regular intervals, which will develop spirit of competition between cities/towns and also enable those who have better rating to access funds from the capital market or float bonds for capital investment.

$\rightarrow$ In view of the wide gap in the provision of basic services and open defecation the grants to be recommended by 14 FC may be invested to meet the basic needs viz., water supply, sanitation, sewerage and storm water drainage and elimination of open defecation. The SMTs - municipalities and NPs - should get priority, as access to services to households and their resource base is weak.

There is a need for continuous political education on the rights and obligations of ULBs and their functionaries.

The boundaries of the ULBs be redefined by incorporating the peripheral or peri-urban and contiguous areas to the existing city or town after the publication of Census reports every ten years.

The good practices in urban governance should be disseminated and become part of training and other capacity building programs. Awareness of good practices, their successes and even the reasons for failure would enable the ULBs to initiate implementing these initiatives/practices with open mind adopting them to the local milieu. 


\section{References}

[1] Appa Rao T., "Visakhapatnam and Its Municipal Government 1858-1998", Sravani Printers, Visakhapatnam, 2000, p.3.

[2] Ibid, p.6.

[3] Ibid, p.7.

[4] Ibid, p.9.

[5] Ibid, p..12.

[6] Ibid, p. 12.

[7] Ibid, p.13.

[8] Ibid, p.13.

[9] Bhardwaj R.K., "The Municipal Administration in India (A Sociological Analysis of Rural and Urban India)", Sterling Publishers, New Delhi, 1970, p. 172.

[10] Ali Asharaf, "Government and Politics of Big Cities (An Indian Case Study)”, Concept Publications, New Delhi, 1977.

[11] Om Prie Srivastva, "Municipal Government and Administration in India" Chugh Publication, Allahbad, 1980.

[12] Mohanty P.K., 'Reforming Property Tax: The Approach of Municipal Corporation of Hyderabad', Center for Good Governance, Hyderabad, 2003.

[13] Madon S, Sahay S and Sahay J., 'Implementing property tax reforms in Bangalore: an actor-network perspective', Information and Organization 14,269-295, July 2004.

[14] USAID, FIRE Project Notes Compilation, Indo-US Financial Institutions Reform and Expansion Project - Debt Market Component FIRE(D), 2004.

[15] Lall S.V and Deichmann U., 'Fiscal and Distributional Implications of Property Tax Reforms in Indian Cities', National Institute of Public Finance and Policy, New Delhi, April 2006.

[16] Mathur O.P and Peterson G., 'State Finance Commissions and Urban Fiscal Decentralization in India', The Urban Institute, Washington, November 2006.

[17] Mohanty P.K, Misra B.M, Goyal R and Jeromi P.D.,'Municipal Finance in India: An Assessment', Reserve Bank of India, Mumbai, December 2007.

[18] Ramakrishna Nallathiga, (2008) Trends and Perspectives of Urban Public Finance in Select Countries and India', ICFAI Journal of Urban Policy, Vol.III, No. 1, pp 16-32.

[19] Sujatha Srinivasan (2009) Financial Disclosure in Local Government: A Comparative Study, Centre of Development Finance, Working paper series.

[20] Gnaneshwar V (2009): 'Property Tax Reforms in India', Urban India, Vol. XXIX (Part 2), Journal of National Institute of Urban Affairs, July-December 2009.

[21] Bandyopadhy S and Rao M.G (2009): 'Fiscal Health of Selected Indian Cities', Policy Research Working Paper No: 4863, the World Bank, World Bank Institute, Poverty Reduction and Economic Management Division, Washington DC, March 2009.

[22] Mathur O.P, Debdulal T and Nilesh R., "Urban Property Tax Potential in India"”, National Institute of Public Finance and Policy, New Delhi, July 2009.

[23] Pethe A and Lalvani M., "A Comparative Study of Municipal Finances in Maharashtra: Patterns, Problems and Prospects”, Atlantic publishers 2011.

[24] Indira A., "Understanding local self governance - An applied research perspective", International NGO Journal, Vol. 6(1), January 2011, pp. 010-013.

[25] Singh Hardeep and. Ashok Purohit, "Finance Income and Expenditure Management of Local Area Government Bodies: A Case Study On Panchkula District”, Asian Journal of Multidimensional Research, Vol.1 No. 1, June 2012, pp.33-42.

[26] Bandyopadhyay S (2012): 'Performance Evaluation of Urban Local Governments: A Case for Indian Cities', International Center for Public Policy, Working Paper 12-32,Andrew Young School of Policy Studies, Georgia State University, Atlanta, USA, October 2012.

[27] Bishnu Prasad Mohapatra, "Local Self-Governing Institutions in India and Fiscal Decentralization: Issues, Challenges and Policy Prescriptions", IOSR Journal of Humanities and Social Science, Vol. 1, No. 6, September-October 2012, pp 41-48. 
[28] Brij Pal, "Financial Aspect of Municipal Basic Services in India: A Study of Haryana State", International Journal of Marketing, Financial Services \& Management Research, Vol.1, No. 12, December 2012, pp.157-163.

[29] Bandyopadhyay S (2013): 'Property Taxation in Indian Cities: A Comparison of Delhi and Bangalore' International Center for Public Policy, Working Paper 13-21 Andrew Young School of Policy Studies, Georgia State University, Atlanta, USA,October 2013,

[30] Bandyopadhyay S and Bagchi D (2013): 'Are User Charges Underutilized in Indian Cities? An Analysis for Delhi', International Center for Public Policy, Working Paper 13-26 Andrew Young School of Policy Studies, Georgia State University, Atlanta, USA, December 2013.

[31] Makandar N. M. , "Financial performance of Selected city municipal corporations in Karnataka", International Journal of Research in Management, Vol. 4, No. 4 , October 2013, pp.1-15.

[32] Patrick Mamboko, Theo Tsokota, Maximillan Giyane and Mhaka Charity, "Meeting the Funding Gap in Urban Local Authorities in Zimbabwe-A Case Study of Gweru City Council", Journal of International Academic Research for Multidisciplinary, Vol.1, No. 8, September 2013, pp.368-380.

[33] Shahid M. Zakaullah, "Urban Challenges in Contemporary India: A Perspective on Urban Local Government", Excellence International Journal of Education and Research, Vol.2, No. 11, November 2014, pp.329-336.

[34] Ravindra Prasad D. Women Empowerment in Urban Governance in India, Indian Journal Of Public Administration, Vol. Lx, No. 3, July-September 2014, pp.42-442.

[35] Hitesh Katya and Raj Kumari,(2014) "Financial Analysis of Urban Local Bodies of India-A Study of Selected Municipal Corporations of Punjab", GALAXY International Interdisciplinary Research Journal, Vol.2, No.3, March 2014, pp. 139-146.

[36] Surbhi Gaur, (2015) "Decentralization and Changing Scenario of Challenges in Urban Local Bodies Finance: An Experience from Rajasthan Cities", International Journal of Research in Humanities \& Social Sciences, Vol. 3, No. 3, March: 2015.

[37] Raj Kumari, (2015) "Financial Performance of Urban Local Bodies in Punjab case Study of Selected Municipal Corporations", International Journal of Business Management and Scientific Research, Vol: 6, June, 2015, pp.25-29.

[38] Sarbjot Singh Behl, Rawal Singh Aulakh, "Historical Analysis of Urban Dynamics of a Traditional Indian City: A Case Study of Walled City Amritsar", Local Government Quarterly, Vol. LXXXVI, No. 1 January-March, 2016, 77-101.

[39] Gopi M., "Urban Local Bodies with Reference to $74^{\text {th }}$ Constitutional Amendment Act of 1992", International Journal of Multidisciplinary Advanced Research Trends, Vol.III, No.1(2), MARCH 2016, p.149-155. 